YEARBOOK Peer-reviewed scientific periodical,

of ANTITRUST

and REGULATORY

STUDIES

www.yars.wz.uw.edu.pl focusing on legal and economic issues of antitrust and regulation. Creative Commons Attribution-No Derivative Works 3.0 Poland License.

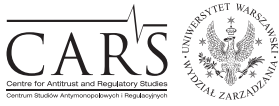

Centre for Antitrust and Regulatory Studies, University of Warsaw, Faculty of Management www.cars.wZ.uw.edu.pl

\title{
The First Cartel Discovered on the Georgian Market. \\ Case Comment to the Decision of 14 July 2015 on the Car Fuel Commodity Market
}

(Order No 81 of the Chairman of the Georgian Competition Agency)

\author{
by
}

\section{Zurab Gvelesiani* $^{*}$}

\section{CONTENTS $^{* *}$}

I. Background

II. Facts and figures

III. Legal barriers identified by the Competition Agency

IV. Key findings and arguments of the decision

1. Timeline of the developments on the fuel market

2. Sun Petroleum's lease agreements

3. Franchising/License Agreements of Rompetrol and LUKOIL

4. Pricing policy

5. Current situation

V. Comments

Key words: hardcore cartel; indirect evidence; pricing policy.

JEL: K21

'Before the Rose Revolution', dozens of companies operated in the retail fuel market. We could buy decent gas, bad gas and black market gas. After the Rose Revolution, the government effectively eliminated the black market retailers as

* SJD candidate at Central European University, Budapest; Gvelesiani_Zurab@phd.ceu.edu.

** Article received: 22 April 2016; accepted: 15 May 2016.

1 The term 'Rose Revolution' is a name given by the media to the events that took place in Georgia in November 2003. Massive anti-governmental demonstrations forced the late president Eduard Shevardnadze to resign, bringing Mikheil Saakashvili and his United National 
new companies emerged and began to consolidate their presence. One by one, independent gas stations were swallowed up by bigger fish. Now, only 5 suppliers operate on the Georgian market. [...] If one liter of gasoline is $2.50 \mathrm{GEL}$ at Gulf ${ }^{2}$, you can bet it will pretty much be the same price at Wissol, Lukoil, Rompetrol and Socar.'

(Rimple, 2012)

\section{Background}

An oligopoly and a presumed cartel on the fuel market used to be a widely discussed issue and topic of endless speculations in Georgia for years. It was an issue frequently covered by the media, discussed by politicians, studied and analysed by the NGO sector, examined by various experts and commented on by academics. In the absence of competition rules, the fuel market was often used as proof of the unhealthy development of the Georgian economy, in order to demonstrate the need for state intervention (Rimple, 2012; Transparency International Georgia, 2012). It thus came as no surprise that when Georgian Competition Law (hereafter, GCL) ${ }^{3}$ was adopted, and the Georgian Competition Agency (hereafter, GCA or Agency) started functioning, the first segment of the economy which the Agency choose to investigate on its own initiative was no other but the fuel commodity market. It was a strategically well chosen subject, which would attract the attention of the public as well as of businesses. It would popularize the new legal field as well as make an example and establish new standards for fair business practices in Georgia.

However, as well chosen as the fuel market might have been, it was equally challenging to achieve the abovementioned objectives successfully. First of all, the expectations toward the newly created Agency were generally high. Moreover, the GCA had to face the challenges of establishing completely new standards of competition law proceedings. Additionally, not only would the Agency have to analyse the long evolution and operations of the specific and complex fuel market, without having any relevant experience to fall back upon, it would have to do so in a period of time marked by a global change in oil prices. Indeed, after a set of geopolitical developments, previously stable oil

Movement into power. For more information see: (BBC News, 2005); (Kandelaki, 2006); (United States Institute of Peace, 2016); (Coppieters and Legvold, 2005); (Lincoln, 2013).

2 It needs to be clarified that the competition Agency decision does not directly mention Gulf, but instead it refers to Sun Petroleum Georgia LLC, the company that developed the network of Gulf filling stations and which presents the brand in Georgia. For more information about the company, see: http://gulf.ge/en/gulf-georgia/about-company (23 April 2016)

3 Law of Georgia of 8 May 2012 No. 6148-Is on Competition. 
prices started to fall sharply in July 2014 (The Economist, 2014; Krauss, 2016), and yet this trend was not reflected in Georgia to a similar degree (Association of Young Financiers and Businessmen, 2015; Business Week Caucasus, 2014). Importantly, the GCA was set up to be accountable to the Prime Minister of Georgia $^{4}$ and it was he who gave the Agency 10 days, in mid-December 2014, to analyze and prepare a detailed report on the state of the national fuel market. The purpose of that report was to identify the reasons for the inadequate fall in fuel prices in Georgia in light of the global price decrease in crude oil 5 . The Agency's preliminary report was presented to the Prime Minister, after which he stated that the public had 'every reason to be dissatisfied' by the performance of the companies on the fuel market (Kirtzkhalia, 2015).

\section{Facts and figures}

On 12 November 2014, the GCA started an investigation of the national fuel commodity market. According to the GCL, after opening an investigation the Agency should take a decision within a period of 3 months, although the investigation may be extended to up to 10 months, depending on the significance and complexity of the case ${ }^{6}$. The GCA was unable to deliver a decision within the original 3 months and twice extended the investigation period $^{7}$. Ultimately, it took 8 months and 2 days before the investigation was concluded and the decision rendered. In order to better demonstrate the scales of the investigation, it is useful to provide some basic statistical data and figures. The Agency studied the developments on the fuel market between 2004 and 2015 (with particular emphasis on the period between 2008 and 2014) that resulted in 1200 pages long decision. Aside from communicating with hundreds of undertakings ${ }^{8}$ operating on the fuel market (as well as

\footnotetext{
4 Article 16 (3) GCL.

5 For more information, see: http://gov.ge/index.php?lang_id=ENG\&sec_id=387\&info_ $\mathrm{id}=46123$ (23 April 2015).

6 Article 25 (1)(2) of GCL.

7 On 12 February 2015, with order N20, the Chairman of the Agency extended the investigation until 31 May 2015. On 29 May 2015, the order N20 was amended and the investigation period was extended until 31 July 2015. For more information, see: Order N81 (14 July 2015) of the Chairman of the Competition Agency, p. 3.

8 It is necessary to allay the confusion regarding the terms in the GCL. The Georgian text of the Law uses the term 'economic agent' (Art. 3(a)) meaning: an undertaking. However, it is not clear how it should be translated into English. An unofficial translation of the Law published on the GCA website uses the term 'economic agent'. The same term has been used in practice by the Agency when making English language announcements, reports or case reviews. However,
} 
on neighbouring markets) currently or in past years, arranging individual meetings with them and requesting that they provide data and explanatory statements, the GCA also repeatedly asked for information from 15 different state institutions and 15 banks operating in Georgia. Additionally, it requested access to studies and held consultation meetings with a number of NGOs, state officials and public bodies, with experts and academics. Moreover, the GCA requested data from the Armenian Competition Authority ${ }^{9}$ as well as consulted representatives of German and Italian Competition Authorities.

The GCA finally issued its decision on 14 July 2015 finding that a cartel has been operating on the Georgina fuel market. In total, the Agency fined 30 undertakings although it identified the 'Big Five' as the core of the cartel. In fact, the cartel included all of the five large-scale undertakings operating on the Georgian fuel market: SOCAR Georgia petroleum LLC ${ }^{10}$ (hereafter, SOCAR), Sun Petroleum Georgia LLC (hereafter, Sun petroleum), Rompetrol Georgia LLC ${ }^{11}$ (hereafter, Rompetrol), JSC Wissol Petroleum Georgia (hereafter, WISSOL) and LUKOIL-Georgia LLC (hereafter, LUKOIL). The Agency identified also 3 other undertakings that did not operate on the retail market but were active on the wholesale level, which were in close vertical relations with various members of the 'Big Five'. These included: L Oil LLC (closely linked with LUKOIL), Binuli 1 LLC (closely linked with Rompetrol) and ITI LLC (closely linked with SOKAR). Additionally, the decision was addressed to 21 limited liability companies and one sole proprietor, which had franchising/license agreements with either LUKOIL or Rompetrol.

The total sum of the fines imposed upon the infringers totalled 54702729 GEL (21935 491 EUR $)^{12}$, an unprecedented amount for Georgia. Out of this amount, 51661228 GEL (20715866 EUR) went to the members of the 'Big Five'13,

the translation of the Law published on matsne.gov.ge translates the term as 'undertaking'. Matsne.gov.ge is the Legislative Herald of Georgia, meaning that the normative acts acquire legal effect only after being published therein. It also offers official translations of national legislation. While it is presumable the translation made by matsne.gov.ge is correct, the GCA needs to adjust its own and use the same terminology to avoid confusion.

9 The State Commission for the Protection of Economic Competition of the Republic of Armenia.

10 SOCAR Georgia Petroleum is a daughter company of State Oil Company of the Azerbaijan Republic - SOCAR

11 Rompetrol Georgia is part of KMG International N.V. (the former The Rompetrol Group N.V.)

12 For the official exchange rates of GEL against other currencies on the day of the GCA decision, see: https://www.nbg.gov.ge/index.php? $\mathrm{m}=582 \& \operatorname{lng}=$ eng

13 The amounts of the individual fines are: SOCAR - 14381385 GEL (5 823366 EUR), Sun Petroleum - 11267384 GEL (4562 432 EUR), Rompetrol - 10845806 GEL (4 391725 EUR), Wissol - 10426393 GEL (4 221895 EUR), LUKOIL - 4740260 GEL (1919 444 EUR). 
3037101 GEL (1217860 EUR) was imposed on the three aforementioned wholesale distributors ${ }^{14}$ closely linked with the 'Big Five'. Each of the remaining 22 undertakings was fined with a symbolic 200 GEL (80 EUR).

None of the members of the 'Big Five' settled with the GCA or admitted committing an infringement. Moreover, each of them has individually appealed the decision (BPI, 2015; Civil Georgia, 2015; Georgian Journal, 2015). So far, the Tbilisi City Court has only ruled on the SOCAR's appeal upholding the original decision of the GCA (Georgian Business Consulting, 2016a). The Agency hopes this ruling will become a precedent for the remaining appeal cases. However, SOCAR remains defiant and plans to take the case before the appellate court (Georgian Business Consulting, 2016b).

\section{Legal barriers identified by the Competition Agency}

Issuing its first significant decision after conducting a long and complex investigation, the GCA identified in the decision several problems in Georgia's existing legislation. According to the Agency, these shortcomings decrease the effectiveness of the GCA's performance and make it particularly hard for the Agency to gain access to any direct evidence of a competition law infringement. According to the GCA, the current law irrationally limits its authority, and due to poor legal provisions, the Agency faces serious challenges in its investigative process ${ }^{15}$. The GCA indicated that the law allows conducting on-site inspections of undertakings on the basis of an a priori judicial consent ${ }^{16}$. According to the GCA's interpretation of the Administrative Procedural Code, and of the law on the Control of Entrepreneurial Activity, the Agency is unable to conduct dawn-raids in a surprise manner because when it applies to a court for such consent, the court is legally required to inform the targeted undertaking of that fact before taking a decision in the matter. As such, this allows the alleged infringer to destroy potential evidences. The GCA stressed therefore the need for the law to include special provisions allowing it to conduct on-site investigation without a prior court approval.

The Agency is currently entitled to invite interested parties to hear their explanations ${ }^{17}$ and yet the law does not provide for any measures to be taken

14 The amounts of the individual fines are: L Oil - 1209890 GEL (489913 EUR), ITI 1172766 GEL (474 880 EUR), Binuli 1 - 654445 GEL (265 000 EUR).

15 For a detailed analysis see: Order N81 (14/07/2015) of the Chairman of the Competition Agency, Part V. Review of the Problems in the Competition Legislation, p. 71-75.

16 See: Article 18 (1(e)), Article 25(8) GCL.

17 Article18 (1(d)), Article 25(6) GCL. 
in case the invited party fails to appear. Moreover, the GCA lacks the power to force a requested entity to appear which ultimately makes the participation of the latter in the investigative process rather voluntary.

According to Article 25(7) GCL, the Agency may carry out an on-site inspection of an undertaking against whom an application and/or complaint is submitted. However, the GCA can also open an investigation on its own initiative $^{18}$, this Article should allow the Agency to perform on-site inspections for any type of case, no matter whether it is based on an application and/or complaint or not.

Moreover, the Agency mentioned its limited access to data collected by the National Statistics Office (Geostat), which can often be vital and extremely relevant for competition law investigations. While the GCA is entitled to request information from any state authority, the procedure should follow the rules laid down by the legislation of Georgia ${ }^{19}$. The Law on Official Statistics declares that data collected for the purpose of creating official statistics is confidential where it might reveal the identity of its source or enable such identification to be established ${ }^{20}$. Although legal exceptions regarding limited access to confidential information exist in Georgian legislation, none of them apply to the GCA, making the data gathered by Geostat inaccessible to the Agency.

Finally, the Agency indicated that its authority is rather limited in case of on-site investigation. It can access the place where the activities of the undertaking are conducted, and examine all the documents related to professional activities, including financial/economic documents, irrespective of their confidentiality. However, according to the GCA, it is not allowed to check private correspondence, work email, tap or take recordings of phone call, conduct searches within the properties of a case-related person, or anywhere else where evidence can possibly be kept. To prove the validity of its point, the Agency brought forward examples of Spanish, German, Italian, Israeli, Swedish and Polish legal models, all of which provide their competition authorities with much broader investigative powers.

Inserting a review of the various shortcomings of existing legislation into the well publicized fuel-cartel decision served as an advocacy means for the GCA meant to argue for the extension of its current competences. However, placing such review before the actual assessment of the case served the additional purpose of justifying the lack of direct evidences supporting the arguments

\footnotetext{
18 Article 18 (1(a)) GCL.

19 Article 18 (2(a)) GCL.

20 Article 28 (1)(2) GCL.
} 
of the Agency ${ }^{21}$. The GCA believed that it had direct evidence against two members of the 'Big Five', as well as plenty of indirect evidence, to prove the existence of the overall cartel.

\section{Key findings and arguments of the decision}

\section{Timeline of the developments on the fuel market}

The GCA started the investigation by determining the relevant market. It considered that despite the differences in their features, petrol and diesel are interchangeable goods from the perspective of consumers and suppliers. Moreover, there are separate markets for car fuel and for aviation fuel. Eventually the market was defined as the car fuel commodity market, containing undertakings dealing with petrol and diesel. It is important that Georgia is not a refinery country, nor does it have any fuel production, and so its retail market is fully depended on imports. That is why the Agency paid particular attention to the concentration ratio of the import structure and presented yearly statistics on the number of importing undertakings along with the Herfindahl-Hirschman Index (hereafter, HHI) of concentration.

In 2004, 178 undertakings imported fuel and the concentration ratio was at a low HHI of 279.2. In 2005, 19 undertakings left the market; 159 remained with a HHI set at 572.46. By 2006, the number of importers fell to 142 with a HHI of 534.6. In 2007, there were 113 undertakings left on the market, however 15 of them controlled $90 \%$ of the import. Eventually, the concentration ratio went from low to moderate and reached a HHI of 1461.13. By 2008, as many as 82 undertakings left the Georgian market and only 31 remained. At that point in time, the import market moved to a high concentration level and reached a HHI of 2799.46.

Importantly, along with the decreasing number of importers, the actual import size has been steadily increasing over the years. Moreover, in 2004 fuel was imported into Georgia from a number of countries, by various wholesalers and retailers, none of which had exclusivity (except Eko Georgia LLC which was the only importer from Greece). By 2008, a small group of undertakings started to dominate imports while the activities of others significantly decreased. There are two traditional routes of importing fuel into

21 A similar style of 'excuses' can be found in several other places in the decision, where it is stressed that the Agency is very new, it is only now creating its own databases and this is the first time it has to deal with and analyse such a vast amount of information. 
Georgia: 1) from the east - from/through Azerbaijan and 2) from the west through the Black Sea. By 2008, after SOCAR and Rompetrol increased their activities, import barriers appeared. In fact, importers started increasing their presence on the retail level acquiring or leasing existing petrol stations. By 2009, 25 undertaking imported fuel into Georgia (HHI of 2445.4). As SOCAR started to dominate imports from Azerbaijan, other undertakings were only rarely and selectively given the opportunity to import from that region. In the second half of 2009, the process of establishing artificial barriers intensified and the most active cartel-forming phase commenced.

After a slight decrease in the size of imports in 2009, they grew once again in 2010 - but conducted solely via 12 undertakings (HHI of 2757.72). Since 2008, imports have been dominated by SOCAR, which imported nearly half of all fuel consumed in Georgia. Between 2009-2011, a massive market exodus took place that included companies which had until then been wellestablished on the Georgian market such as: Senta Petroleum LLC, Eko Georgia LLC, Magnati 2006 LLC, Intercompany LLC, Luck Bunker LLC and others. Explanatory statements provided by these companies demonstrated the difficulties which they had been facing in that period of time. They claimed that after SOCAR gained control over imports from Azerbaijan, other undertakings had lost the possibility not only to import from that region, but also to transit goods through Azerbaijan - albeit rejection reasons varied. Undertakings were also frequently unable to import from the western direction for example due to unreasonable refusals to use a port's docking facilities (e.g. for technical reasons). Furthermore, after the market entry of Rompetrol, imports from Romania became inaccessible. Undertakings unable to import by themselves, which wanted to purchase goods from members of the 'Big Five', were frequently rejected due to (claimed) lack of resources. Alternatively, they were offered the requested goods, but at an inflated price (set at a nearly retail level). Some undertakings claimed that certain state authorities assisted selected companies by imposing sanctions upon others, in order to make them exit the market. However, the GCA stressed that apart from the abovementioned explanatory statements, no other evidence exists proving the participation of state institutions in the process of establishing artificial import barriers ${ }^{22}$.

${ }^{22}$ For demonstrational purposes, the decision discussed the case of the Dedoplistskaro municipality where 8 undertakings had operated 12 petrol stations, until they were all obliged to stop their activities in 2010-2011. They disclosed in their explanatory statements that they had faced serious problems with the wholesale purchase of fuel. This happened in the harvest period, which in this agricultural region is the best business period. Unable to purchase fuel, they all gradually stopped operating. Some on the petrol stations were sold or leased to members of the 'Big Five', the rest were shut down. The Agency considered the case is evidence of the 
In 2011, 10 undertakings imported fuel into Georgia - 8 principal importers, out of which 1 undertaking left the market while another was dependent on Sun Petroleum. Hence, there were actually 6 importers and the concentration ratio reached a high level of HHI 3106.83. By 2012, 8 agents import the goods in question with a HHI of 2917.46. Overall, between 2010 and 2012, members of the 'Big Five' were the predominant operators on the Georgian fuel market with a number of other undertakings closely related to them. All other competitors were eliminated -662 petrol stations stopped operating.

Sun Petroleum entered the market in 2011 and leased, within a short period of time, 91 petrol stations from undertakings exiting the Georgian market; it soon became one of the largest actors on the national market with the highest number of petrol stations. Meanwhile, the four companies already dominating the national market, known to act aggressively against other competitors, have shown no particular reaction to the expansion of Sun Petroleum and did not actively compete with it.

\section{Sun Petroleum's lease agreements}

Sun Petroleum gained control over dozens of petrol stations by leasing them. During its investigation, the GCA analysed these contracts and discovered that their absolute majority is extremely one-sided and tailormade to suit the interests of Sun Petroleum. The lessors are paid very low rent when compared to market prices. Duties typically imposed on lessees are instead placed on lessors, for example the latter are obliged to bear the expenses of renovating and "rebranding" the petrol stations. Lessors' rights to visit their property are limited and depend on the consent of Sun Petroleum. The latter is allowed to sublet the petrol stations without the consent of the owners. While the lessee can easily withdraw from the contracts, lessors are virtually unable to terminate them. Overall, the content of these contracts raised suspicions that dozens of undertakings decided to exit the Georgian market at the same time and entered into extremely unfavourable contractual relationships with a recently established company, agreeing on low rent rates, without a withdrawal mechanism. The negative impact of these contracts continues until today since the majority of the lessors remain their 'prisoners'. In the absence of these contracts, they could re-enter the market and generate

coordinated behaviour of the cartel members. Moreover, the GCA assumed that the dominant undertakings needed to enter Dedoplistskaro, as well as other provincial regions, in order to be present all around the country, a fact that would allow them to participate in consolifated tenders for providing fuel to state institutions. 
far higher profits comparing to the minimal lease rates which they currently get on the basis of the unfavourable lease agreements.

\section{Franchising / License Agreements of Rompetrol and LUKOIL}

A high number of the petrol stations operating under the brands of LUKOIL and Rompetrol are independent undertakings, which are under license/franchising agreements with the two aforementioned large companies. In the case of Rompetrol, its contracts explicitly fix prices - by contrast, LUKOIL agreements are only oral, and yet still complied with in practice, a fact confirmed by explanatory statements and by a comparative price analysis. While Article 613 of the Civil Code of Georgia allows franchisors and franchisees to be in 'loyal competition' with each other, it is illegal to directly fix prices. The GCA referred to the decisions of German and Polish competition authorities to claim that fixing prices for franchising/license agreements is a competition law infringement. Moreover, according to EU practice, only non-binding recommendations can be tolerated.

\section{Pricing policy}

The GCA identified parallel pricing practices on the fuel market. Fuel prices were always analogous among the 'Big Five'. Moreover, the Agency concluded that the prices were fixed and not determined by economic factors, a realisation proven by the fact that prices were identical in the whole territory of the country. For example, 1 litter of petrol costs the same in one border town (despite no extra transportation costs) and in a town hundreds of kilometres away on the opposite border of the country. Moreover, at the latter border, other companies import the goods for a cheaper price and yet they fail to use this advantage to cut prices in order to compete. The GCA stressed that LUKOIL was particularly hesitant to compete and utilise its cost advantage (considerably lower operational expenses), which was again seen as indicative of coordinated behaviour among the companies. The artificiality of retail prices was demonstrated by the fact that, in December 2014, when Rompetrol and Lukoil simultaneously submitted offers to a state consolidated tender to sell 'Premium' fuel, both their offers were 1.57 GEL, despite the fact that retail prices were at that time set between 2.06-2.08 GEL. The fact that the 'Big Five' exploited and coordinated their dominance in order to maximize their profit is evident in the fact that in 2012 fuel consumption increased in Georgia by $10 \%$ comparing to 2008 and yet the income of the companies increased by 
205\%. Eventually, excessive profits and coordination among cartel members allowed them to make some economically irrational investments, which they made based on expectations of guaranteed high profits.

\section{The current situation}

The GCA came to the conclusion that artificial import barriers were eliminated and positive structural changes started on the Georgian fuel market in $2013^{23}$. By that time, 25 agents were already importing the goods in question resulting in a $\mathrm{HHI}$ of 1790.04 . The number of importers decreased again in 2014 to 19 (HHI 1938.42). Still, as imports became accessible once again, more undertakings started to return or enter the market. By February 2015, Georgia had 963 petrol stations in operation - 538 belonged to the 'Big Five', the remaining 425 were 'non-branded'. Despite these positive developments, change is slow and it is clear that the negative impact of the developments of 2008-2012 will continue. For example, by 2014, the 'Big Five' controlled $93 \%$ of the total import of fuel. An additional challenge lies in the fact that some of the companies that recently returned or newly entered the Georgian market do not necessarily compete with the 'Big Five' on the retail level. Rather than offering cheaper fuel prices, some actually prefer to take advantage of the highly concentrated market structure and strategise to keep their own high profit margins by setting similar rates on fuel to those of the 'Big Five'.

\section{Comment}

The discussed case can be called a landmark decision for Georgia simply because it is the first time that the GCA has found a breach of competition law and imposed sanctions upon the infringing undertakings after Georgia adopted its Competition Law in 2012. Moreover, it is obviously its first hardcore infringement case, especially significant as it involves widely consumed goods and a market of vital importance for the national economy.

With regard to the quality of the decision, the Agency has conducted a complex investigation, collected and analysed sizable data and, within the limitations established by the law, still managed to prove the existence of a cartel. However, and unsurprisingly, the decision has some shortcomings.

${ }^{23}$ It is assumed that the breakthrough happened due to political changes in the government of Georgia 
As repeatedly stressed in the decision itself, this was the first large scale investigation conducted by the GCA and so it has proven to be a learning experience for its staff. This is noticeable in the technical mistakes or typos that can be found in the text of the decision, which are obviously not the principal indicators that should be used to evaluate it. Yet it can be argued that in certain areas the arguments of the Agency are not sufficiently well supported. For example, the decision delineated the relevant market simply by indicating that from the consumers' and suppliers' perspective diesel and petrol are interchangeable. Such justification is rather simplistic and is against the modern approach employed in EU, which avoids putting much emphasis over subjective opinion of any group, when determining the market (Albors-Llorens and Jones, 2016) ${ }^{24}$.

Overall, the weakest point of the decision its lack of direct evidence. The GCA stressed that direct evidences against two members of the cartel: LUKOIL and Rompetrol is present. However, these pieces of evidence reveal the existence of price fixing practices of these two companies with their licensees/franchisees - they do not prove the existence of a cartel of the five market leaders.

Furthermore, the Agency indentified in the review of the shortcomings of existing legislation that it lacks the power to access direct evidence, as it cannot conduct surprise on-site inspections because it always needs to get a priori court consent. When conducting on-site inspections, the GCA should, however, follow the rules of the existing Law on the Control of Entrepreneurial Activity and of the Administrative Procedural Code. The GCA complained that neither of these legal acts contains any special provisions concerning the Agency. Yet although it is true that they do not speak specifically of the activities of the GCA, their general rules should be used in this case as they do actually provide for the possibility of starting an inspection without prior approval from a judge ${ }^{25}$. It is unclear why the GCA refused to use the existing mechanism in order to inspect the undertakings in question. Ultimately, it has

${ }^{24}$ For example, EU Commission and the European Court of Justice have been widely criticized for the famous case of United Brands, after they identified the relevant market based on the viewpoint of the certain groups of the final consumers, who considered bananas as the special and not interchangeable with other fruits.

25 The Administrative Procedural Code (Article 212 (1)(2) defines that the controlling body should submit a request to the judge before commencing an inspection of an entrepreneur. However, in case of immediate and direct threat to the evidence, the authority is entitled to suspend the operation of that enterprise and immediately submit a request to a judge. If the operation of an enterprise cannot be suspended, or the suspension significantly damages the enterprise, the authority can commence an inspection and submit an appropriate request to a judge within 24 hours. 
potentially missed out on its only opportunity to access direct evidences that would have made its decision far better supported and proven.

The decision did not estimate the total amount of the damage caused by the existence of the cartel over the years of its functioning. Importantly however, the decision did calculate how much the price per unit had to be and how much the cartel members actually charged on the retail market. If the judiciary ends up upholding the decision of the GCA, any undertaking or individual who suffered damages as a result of this cartel will be able to rely on these numbers to seek damages. Encouraging the development of private enforcement of competition law in Georgia could thus turn out to be a very positive outcome of this investigation.

With regard to the amount of the fines imposed by the Agency, it is hard to evaluate the rationality of the penalty while the actual size of the damage caused by the cartel is unknown. However, the imposed fines are hardly proportional considering the gravity and length of the infringement as well as the number of undertakings and consumers affected. Unlike EU law which has a $10 \%$ turnover cap, Georgian competition law sets the ceiling for competition fines at $5 \%$ of annual turnover. Notwithstanding the above, the GCA has not imposed the maximum amount of fines possible. Whether the fines will prove enough to serve as deterrence, especially since the companies remain fully confident that they had not infringed any laws, is disputable. However, it is commendable that the Agency fined the licensees/franchisees of the main infringers with a symbolic amount only. It was obvious that for them, the participation in the price-fixing practices was not a matter of choice or something they could negotiate.

In fact, the Agency has annulled the offending clauses of the licence / franchise agreements and so the licensees/franchisees are now legally free to determine their own retail prices. Considering the annulment of the price fixing clauses, it is unclear why the Agency did not take similar actions regarding the lease agreements of Sun Petroleum, repeatedly mentioned in the decision as unfavourable to the lessors and a hindrance to their return to the Georgian market. Why has the Agency failed to intervene against this member of the 'Big Five' that continues to maintain very effective market barriers keeping potential competitors from returning to the market?

Despite the abovementioned problems, is a very positive development for the Georgian competition law sphere that the GCA started to function actively, investigated one of the most problematic markets in the country and ultimately detected and fined an operating cartel. It is essential for the Agency to learn from this experience and to extend its activities to other problematic markets. 


\section{References}

Association of Young Financiers and Businessmen. (16 January 2015). Gas prices on Georgian market are inadequate to that of international market. Retrieved from: http:// afba.ge/en/news/index/116.

BBC News (10 May 2005). How the Rose Revolution happened. Retrieved from: http:// news.bbc.co.uk/2/hi/4532539.stm.

BPI. (6 August 2015). Oil Companies to Sue the Competition Agency's Conclusion. http:// bpi.ge/index.php/oil-companies-to-sue-the-competition-agencys-conclusion/?lang=en.

Business Week Caucasus. (22 December 2014). Global price on fuel declines considerably by $48 \%$, while Georgian prices decrease by $13 \%$. Retrieved from: http://cbw.ge/business/ global-price-on-fuel-declines-considerably-by-48-while-georgian-prices-decrease-by-13/.

Civil Georgia. (17 July 2015). SOCAR, Sun Petroleum Dispute Multi-Million Fines Imposed by Competition Agency. Retrieved from: http://www.civil.ge/eng/article. php?id=28445.

Coppieters, B. and Legvold, R. (2005). Statehood and security: Georgia after the Rose Revolution. Cambridge: American Academy of Arts and Sciences.

Georgian Business Consulting. (11 April 2016a). The court left a fine of 14 million, imposed on "SOCAR", under the force http://gbc.ge/index.php? $\mathrm{m}=$ tst.

Georgian Business Consulting. (12 April 2016b). SOCAR plans to continue fight against Competition Agency. http://gbc.ge/index.php?m=tst.

Georgian Journal. (24 July 2015). The Cartel-ificent Five - Determining real owners of the 'Big Five' is harder than catching a black cat in a dark room. http://www.georgianjournal. ge/business/31083-the-cartel-ificent-five-determining-real-owners-of-the-big-five-isharder-than-catching-a-black-cat-in-a-dark-room.html?fb_comment_id $=84833012191$ 1129_848386001905541\#f954840d723b3.

Jones, A. and Albors-Llorens, A. (2016). The Images of the Consumer in EU Competition Law. In: Leczykiewicz, D. and Weatherill, D. The Image(s) of the 'Consumer' in EU Law. Hart Publishing.

Kandelaki, G. (2006). Georgia's Rose Revolution, Participant's Perspective. United States Institute of Peace, Special Report. Retrieved from: http://www.usip.org/sites/default/ files/sr167.pdf.

Kirtzkhalia, N. (30 January 2015). Georgian PM accuses oil companies of violating competition law. Trend News Agency, retrieved from: http://en.trend.az/scaucasus/ georgia/2358571.html.

Krauss, C. (18 April 2016). Oil Prices: What's Behind the Drop? Simple Economics. NY Times. Retrieved from: http://www.nytimes.com/interactive/2016/business/energyenvironment/oil-prices.html?_r=0.

Lincoln, M. (2013). Uncertain Democracy: U.S. Foreign Policy and Georgia's Rose Revolution. Philadelphia, University of Pennsylvania Press.

Rimple, P. (2012). Who Owned Georgia 2003-2012. Tbilisi: Transparency International Georgia. Retrieved from: http://www.transparency.ge/sites/default/files/post attachments/Who\%20Owned\%20Georgia\%20Eng.pdf.

The Economist. (8 December 2014). Why the oil price is falling. Retrieved from: http:// www.economist.com/blogs/economist-explains/2014/12/economist-explains-4.

Transparency International Georgia. (2012) Competition Policy in Georgia. Tbilisi. 